\title{
Intraspecific morphological and genetic variability in the European freshwater snail Radix labiata (Rossmaessler, 1835) (Gastropoda: Basommatophora: Lymnaeidae)
}

\author{
Katrin Schniebs ${ }^{1,4}$, Peter Glöer ${ }^{2}$, Maxim V. Vinarski ${ }^{3}$, Anna K. Hundsdoerfer ${ }^{1}$ \\ ${ }^{1}$ Senckenberg Natural History Collections Dresden, Museum of Zoology, Königsbrücker Landstraße 159, D-1109 \\ Dresden, Germany \\ ${ }^{2}$ Biodiversity Research Laboratory, Schulstraße 3, D-25491 Hetlingen, Germany \\ ${ }^{3}$ Museum of Siberian Aquatic Molluscs, Omsk State Pedagogical University, Tukhachevskogo Emb. 14, 6440099 \\ Omsk, Russian Federation \\ ${ }^{4}$ E-mail:katrin.schniebs@senckenberg.de
}

Key words: molecular genetics, morphology, Radix labiata, variation

\begin{abstract}
Radix labiata is a widely distributed Palaearctic freshwater snail. This work aims to improve the knowledge of the intraspecific variability in the most important characters used for its determination. To find out which characters are really suitable to distinguish this species from other similar Radix species an integrative approach was applied, involving morphological and molecular data.Molecular sequences of the nuclear spacer fragment ITS-2 and/or the mitochondrial gene fragment cyt-b were obtained from 26 individuals of $R$. labiata from different regions of Europe, including type localities of Limnaeus pereger labiatus. From the subsample of 24 specimens of which sequences of both gene fragments were available, the variability of several characters that are commonly used for species identification (shell morphology, mantle pigmentation, shape and position of the bursa copulatrix, length and position of the bursa duct, length ratio of praeputium to penial sheath) were measured or documented. Morphological characters distinguishing R. labiata from R. balthica, R. lagotis and the genus Stagnicola are discussed. The best morphological character to differentiate these species is the position of the bursa and the bursa duct. Mantle pigmentation and the ratio of the length of the praeputium to that of the penial sheath are not useful for differentiating R. labiata and R. balthica. Analysis of the network of haplotypes (cyt-b) revealed no correlation between recognisable clusters and geography amongst the studied specimens.
\end{abstract}

\section{Contents}

\begin{tabular}{|c|c|}
\hline Introduction & 55 \\
\hline Material and methods & 56 \\
\hline Molecular techniques & 56 \\
\hline Morphology & 57 \\
\hline Results ...................... & 57 \\
\hline Molecular genetics & 57 \\
\hline Morphology ............... & 59 \\
\hline Discussion & 59 \\
\hline Molecular phylogeny & 59 \\
\hline Morphology & 61 \\
\hline
\end{tabular}

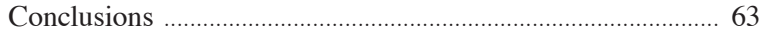

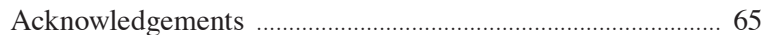

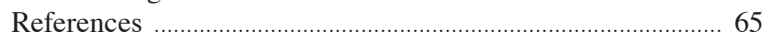

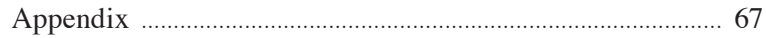

\section{Introduction}

The pond snail Radix labiata (Rossmaessler, 1835) is a Palaearctic species that occurs both in lowlands and mountains. In earlier literature this species has commonly been referred to as 'Lymnaea peregra', 'Radix pereger', or 'Radix peregra'. However, the name R. labiata has been reinstated for the present species by Falkner et al. (2001) while the name Buccinum peregrum O. F. Müller 1774 introduced for specimens from Copenhagen (Frederiksberg) is considered to be a junior synonym of Radix balthica (Linnaeus, 1758) according to Glöer (2002).

In Europe R. labiata is distributed from Norway, Sweden and Finland in the north (Falkner et al., 2001; Welter-Schultes, 2012), to Spain in the west and Italy in the south (Welter-Schultes, 2012), Bulgaria in the southeast (Angelov, 2000; Welter-Schultes, 2012), and the Ukraine in the east (Stadnichenko, 2004; Welter-Schultes, 2012). In Asia it is known from Turkey and the Ural Mountains (Khokhutkin et al., 2009) up to the Irtysh River Basin in the east (Kruglov and Starobogatov, 1983; Kruglov, 2005; Vinarski et al., 2008). In these Russian sources the species is still mentioned under the name Lymnaea (Peregriana) peregra (O.F. Müller, 1774).

Radix labiata prefers small, still or slow-running freshwater bodies but also lives in bogs (Glöer, 2002), in springs or water bodies supplied by ground water (Glöer and Diercking, 2010), in floodplains (Khokhutkin et al., 
2009) and in shallow parts of high-mountain lakes (Angelov, 2000). In Switzerland this species occurs at altitudes up to $2700 \mathrm{~m}$ in small ponds that are free of ice for only three to four months (Turner et al., 1998). The species has also been observed in temporary water bodies (Stadnichenko, 2004; Kruglov, 2005; Vinarski et al., 2008), and in Western Siberia it occurs almost exclusively in such habitats (Andreeva et al., 2010). In lakes and ponds R. labiata is mostly confined to areas that temporarily fall dry during dry seasons (Ward et al., 1996 and own observations). In Sylt (N Germany) it was found in a puddle fed by ground water (Reise and Glöer, 2006). This habitat preference for ground water may explain why this species is rare in lowlands and occurs in mountainous regions.

Caron et al. (2007) demonstrated that $R$. labiata may act as an incidental intermediate host of Fasciola hepatica; Huňova et al. (2012) successfully infected it with Fascioloides magna. Thus, reliable identification is important not only for malacologists working on faunistics and zoogeography but also for parasitologists. Because morphological and anatomical examination is still the fastest method of determination, even in the era of molecular genetics - a method not yet accessible to all malacologists - we consider the study of intraspecific variability to be very important in order to improve the reliability of determination keys. As already established, the shell of $R$. labiata is relatively conserved in its shape (Glöer, 2002; Andreeva et al., 2010) and does not vary as considerably as in R. balthica (Schniebs et al., 2011). However, during morphological examinations we found specimens differing in characters, such as mantle pigmentation, length of the bursa duct and length ratio of praeputium to penial sheath from what has been described in literature. The amount of morphological variation found in the present study raised doubts whether some of the studied specimens really belonged to this taxon. The present work continues our analyses of intraspecific variability that we started with $R$. balthica (Schniebs et al., 2011).

To analyse the variability of the most important distinguishing characters of $R$. labiata (shell morphology, mantle pigmentation, shape and position of the bursa copulatrix, length and position of the bursa duct, and length ratio of praeputium to penial sheath), 26 individuals from several European localities from which we could sequence a $361 \mathrm{bp}$ fragment of the cyt-b gene as a mitochondrial marker were examined. Additionally, we attempted to obtain sequence data of the nuclear ITS-2 spacer for these individuals; this was not successful for every specimen. The variabili- ty of several characters that are commonly used for determination was calculated for the 24 individuals of which both gene fragments were available.

\section{Material and methods}

As type specimens of $R$. labiata for anatomical and genetic analyses are not available, our molecular genetic investigations are based on a specimen from the locus typicus of Limnaeus pereger labiatus Rossmaessler, 1835: Tharandt (Rossmässler, 1835), Saxony (Germany).

All specimens used for molecular and morphological examination are listed in the Appendix. Most were collected or donated for this study and stored in the mollusc collection of the Senckenberg Natural History Collections Dresden, Museum of Zoology (SNSD). Two samples are stored in the collection of Dr Ulrich Bößneck (Vieselbach, Germany).

For outgroup comparison in the molecular genetic analyses we used sequences of specimens of other freshwater molluscs. The outgroup comprised Planorbarius corneus (Linnaeus, 1758), family Planorbidae. We also included sequences of Lymnaea stagnalis (Linnaeus, 1758), R. auricularia (Linnaeus, 1758), R. ampla (Hartmann, 1821), Radix balthica, and $R$. lagotis (Schrank, 1803) in the ingroup.

\section{Molecular techniques}

Tissue samples taken from the foot were fixed in 100\% ethanol. All these were registered in the tissue collection of the SNSD with both a new collection number and the collection number of the specimen in the mollusc collection of SNSD and stored at $-80^{\circ} \mathrm{C}$.

For molecular genetic analyses we obtained sequence data of the complete nuclear ITS-2 spacer (280$495 \mathrm{bp}$ ) and a $361 \mathrm{bp}$ fragment of the cyt-b gene as mitochondrial marker. For primers and protocols of DNA extraction, Polymerase Chain Reaction (PCR), purification of PCR products and DNA sequencing see Vinarski et al. (2011). Alignments were performed using the sequence alignment editor BioEdit (Hall, 1999). The ITS-2 alignment was obtained using the Clustal algorithm of MEGA4 (Tamura et al., 2007) and improved by eye. Genetic distances for cyt-b were calculated using MEGA4 (Tamura et al., 2007). The data set consisted of $361 \mathrm{bp}$ of 26 individuals. This program was also used to produce the dataset of cyt-b sequences (positions with missing data were excluded: $318 \mathrm{bp}$ ) for network analyses (median joining; Bandelt et al., 1999) 
with the program 'Network' (www.fluxus-engeneering. com). Maximum-parsimony (MP) trees were reconstructed using PAUP (version 4.0b10; Swofford, 2002; settings: gapmode $=$ NewState, addseq $=$ closest , maxtree $=100$; number of bootstrap replicates $=10000$ ). For maximum-likelihood analyses, including bootstrap support, we used RAxML (raxmlGUI 0.9 beta 2, Stamatakis et al., 2005; Silvestro and Michalak, 2010). The settings were 'ML+thorough bootstrap' with 100 (replicate) runs and 1000 (bootstrap) repetitions.

\section{Morphology}

The snails were fixed in 70-80\% ethanol. The shell morphology, mantle pigmentation and anatomy of the specimens studied were recorded. The dissections and measurements of the genital organs and shells were carried out using stereo microscopes (Zeiss and Olympus); photographs were taken with a digital camera (Leica R8). For the taxonomy we followed the current European checklists (Falkner et al., 2001; Bank, 2011).

\section{Results}

\section{Molecular genetics}

Uncorrected genetic distances (p-distance) from pairwise comparisons of cyt-b sequences (fragment of 361 bp) are shown in Table 1. Pair-wise distances between species of the families Planorbidae and Lymnaeidae (outgroup comparison) ranged between $31 \%$ and $28 \%$. Distances between the two genera analysed in the family Lymnaeidae (only sequences of Lymnaea stagnalis and all Radix species) ranged from $25 \%$ to 20\%. Among the five Radix species analysed, the highest values are between $R$. auricularia and the other species (15\%-18\%). R. labiata, $R$. balthica, $R$. ampla and $R$. lagotis exhibit smaller pair-wise distances between $9 \%$ and $16 \%$.
As for molecular phylogeny, the maximum-parsimony (MP) tree of the nuclear marker ITS-2 (tree length $=996$, consistency index $=0.9046$, retention index $=0.9718$ ) basal branches received high or full bootstrap support by means between $98 \%$ and $100 \%$ (Fig. 1). Species-clades are generally fully supported. Radix auricularia is sister group to all other Radix species. Radix balthica is the sister group of $R$. am$p l a$; together they form the sister group of $R$. lagotis. All specimens identified as R. labiata or $R$. cf. labiata by means of anatomy fall into one cluster with bootstrap support of $100 \%$.

The RAxML tree of the ITS-2 spacer (not shown) differs in two main aspects from the MP tree: 1) The bootstrap supports of the basal branches and of the species-clades are lower in most cases and the tree shows a polytomy between $R$. balthica, $R$. ampla and $R$. lagotis. 2) Radix auricularia groups as a sister to R. labiata with bootstrap support of 78\%. All specimens identified as $R$. labiata or $R$. cf. labiata on the basis of anatomy still fall into one cluster with full bootstrap support.

The maximum-parsimony (MP) tree of the cyt-b sequences (tree length $=336$, consistency index $=$ 0.6845 , retention index $=0.8997$ ) (Fig. 2) has low or very low support for most of its basal branches. The very low support is also expressed by a polytomy of $R$. auricularia and the other Radix species. The clades of the species themselves have high, often full support except for R. ampla (70\%). All specimens identified as R. labiata or $R$. cf. labiata by means of anatomy fall into one cluster with high bootstrap support (91\%).

In the RAxML tree of the cyt-b sequences (not shown) most of the basal branches show very low support. This very low support is again expressed by a polytomy of $L$. stagnalis, $R$. auricularia, $R$. balthi$c a, R$. lagotis, and R. ampla, to which the cluster of $R$. labiata groups as a sister with support of $77 \%$.

The network representation of cyt-b mitochondrial

Table 1. Uncorrected pair-wise p-distances of the cyt-b gene fragment (361 bp) calculated using MEGA version 4 (Tamura et al., 2007).

\begin{tabular}{|c|c|c|c|c|c|c|c|}
\hline & P. corneus & L. stagnalis & R. balthica & R. lagotis & R. auricularia & R. ampla & R. labiata \\
\hline Lymnaea stagnalis & 0.282 & - & - & - & - & - & - \\
\hline Radix balthica & 0.308 & 0.225 & - & - & - & - & - \\
\hline R. lagotis & 0.281 & 0.199 & 0.086 & - & - & - & - \\
\hline R. auricularia & 0.301 & 0.251 & 0.146 & 0.156 & - & - & - \\
\hline R. ampla & 0.278 & 0.203 & 0.112 & 0.090 & 0.185 & - & - \\
\hline R. labiata & 0.281 & 0.225 & 0.130 & 0.123 & 0.174 & 0.109 & - \\
\hline
\end{tabular}




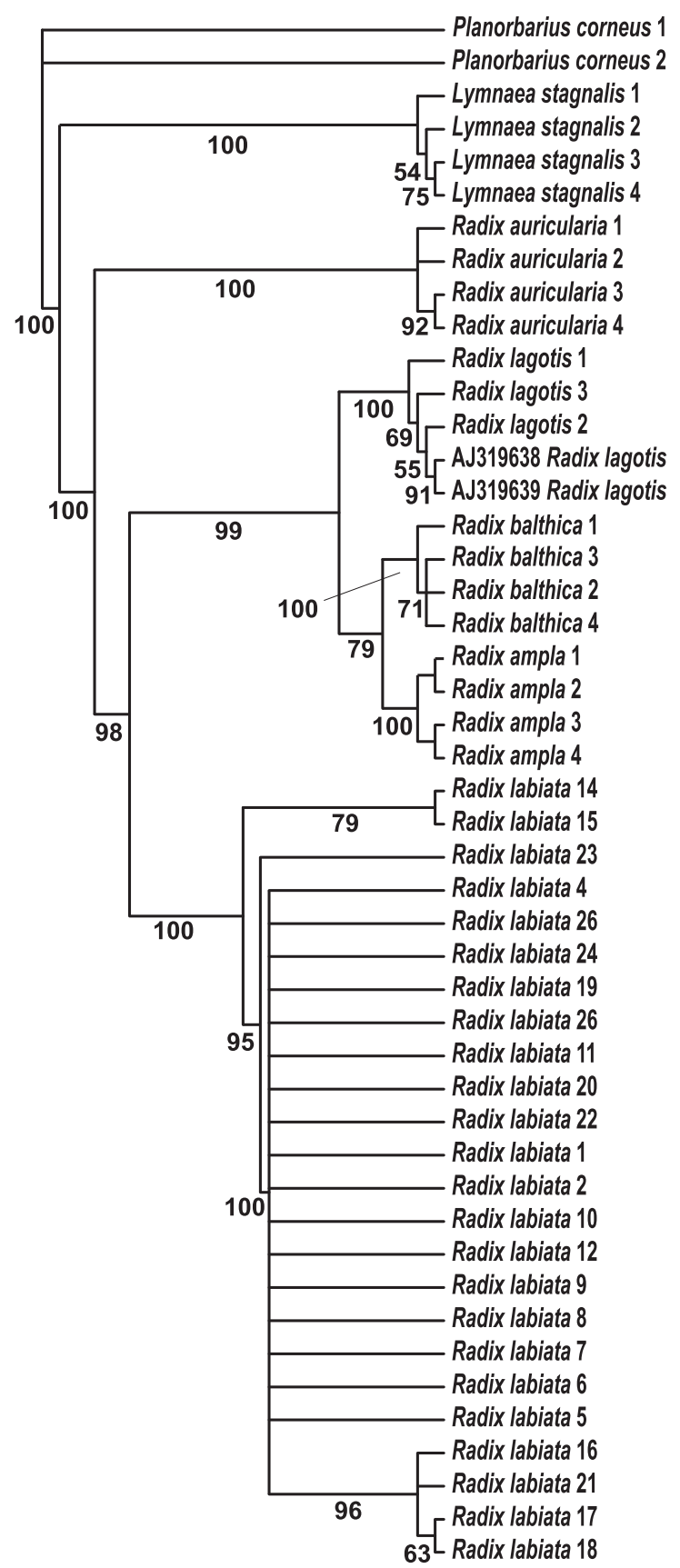

Fig. 1. Hypothesis for the phylogenetic relationships of Radix labiata: on the strict consensus of 100 maximum-parsimony trees of the nuclear marker ITS-2 (tree length $=996$, consistency index $=0.9046$, retention index $=0.9718)$. Branch lengths are proportional to the number of substitutions and the overall topology corresponds to that of the strict consensus tree. Bootstrap support values above $50 \%$ are reported below nodes.

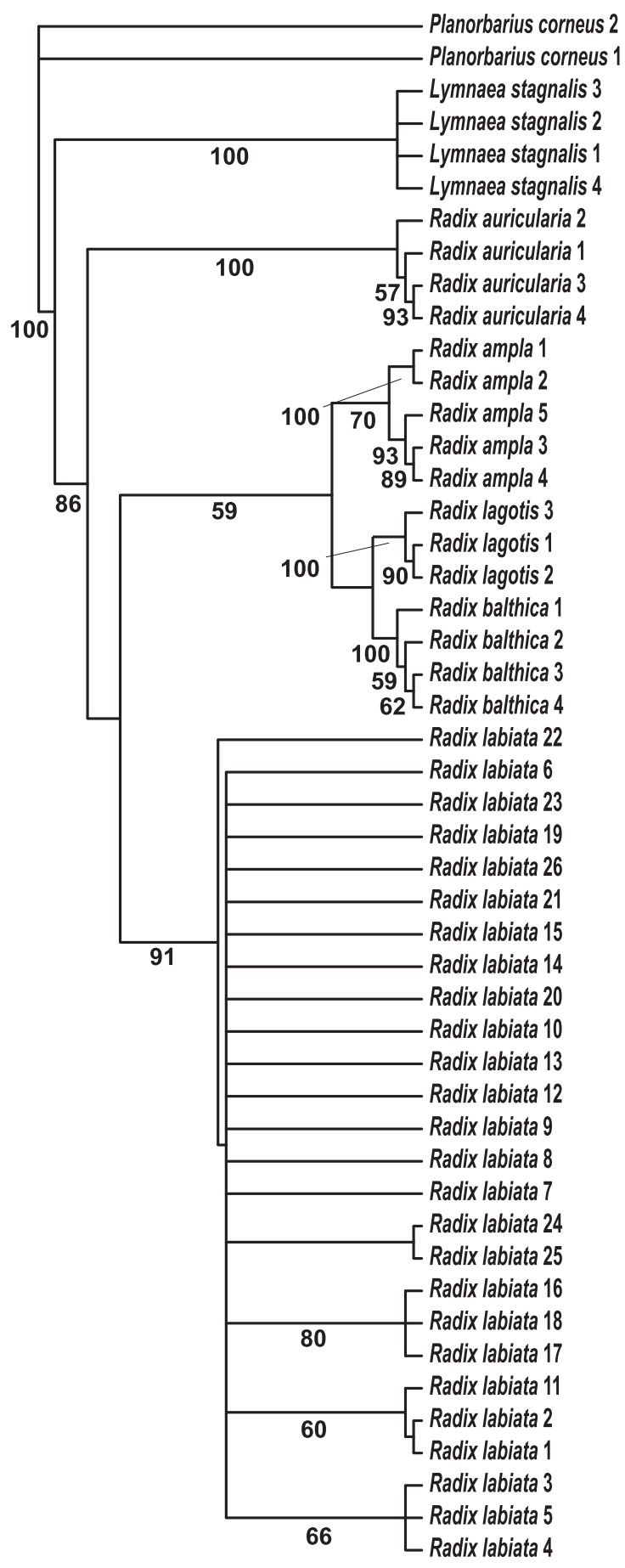

Fig. 2. Hypothesis for the phylogenetic relationships of R. labiata: on the strict consensus of 100 maximum-parsimony trees of the fragment sequenced of the mitochondrial marker cyt-b (361 $\mathrm{bp}$; tree length $=336$, consistency index $=0.6845$, retention index $=0.8997$ ). Branch lengths are proportional to the number of substitutions and the overall topology corresponds to that of the strict consensus tree. Bootstrap support values above $50 \%$ are reported below nodes. 
sequences (318 bp, Fig. 3) of 26 R. labiata specimens from different locations in Europe shows scarcely reticulated differentiation of about 16 sites showing variation between individuals. Between individuals from geographically close localities, for example from within Saxony in Germany (blue), differentiation of 9 substitutions could be observed.

\section{Morphology}

The shell morphology of the examined specimens $(n=24)$ varied from slender, close to the shape of Stagnicola, to a conical egg-shape (Fig. 4). They varied from thin-walled and fragile to solid, and from a light horn colour to reddish-brown. The shell height ranged from 7.5 to $16.8 \mathrm{~mm}$ and the number of whorls between 3.5 and 4.0 in 9 specimens with preserved first whorls. The shell form varied not only between specimens from different localities but also varied between specimens collected from the same locality (Fig. 5).

The mantle pigmentation of the sequenced specimens of $R$. labiata $(n=24)$ is polymorph (Fig. 6). It was however possible to distinguish three main types:

- mantle black or deep blue-black with irregular fine whitish dots of similar size, mantle collar black or blue-black, mantle edge bluish grey or whitish with some irregular patches of black or deep blueblack (Fig. 6a-b, 6d);

- mantle black or grey with numerous, mostly roundish small distinct spots of white, white-gray or rarely grey-green that are very variable in size; mantle collar bluish-grey or whitish-grey with diffuse patches of black; mantle edge and tentacles whitish, blue-grey, brownish-grey or gray-orange (Figs 6c, 6e);

- mantle black or grey-black with roundish patches, mostly of similar size of white or lighter greyblack; mantle collar bluish grey with irregular patches of black; mantle edge blue-grey (Fig. 6f);

The measurements of praeputium and penial sheath of 21 specimens are reported in Table 2 (see also Fig. 7). The ratio of the length of the praeputium to that of the penial sheath varies from 0.58-2.53 $(n=21)$. The praeputium is pigmented grey in most specimens. In a few cases it shows a grey-green or whitish-yellow colour.

For the bursa copulatrix, the following three characters were analysed (Fig. 8):

- Position of the bursa copulatrix $(n=20)$. The bursa was positioned behind (ventral to) of the provagi- nal duct and the vagina in most specimens examined $(n=17)$. In three specimens the bursa was positioned beside the provaginal duct. But in all cases the bursa duct entered on the ventral side of the provagina above female vent.

- Shape of the bursa. This varied from egg-shaped, to pear-shaped, to elongate pear-shaped, to club-shaped.

- Length of the bursa duct $(n=21)$. The length of the bursa duct varied between nearly not visible $(n=7)$ up to a length of between 3 and $5 \mathrm{~mm}(n=12)$, and even to $7 \mathrm{~mm}(n=2)$.

\section{Discussion}

\section{Molecular phylogeny}

The main aim of the molecular genetic analyses was to find out whether the specimens with unusual morphology or anatomy belonged to the species R. labiata and

Table 2. Measurements of the male genitalia of 21 specimens.

\begin{tabular}{|c|c|c|c|}
\hline Collection No. SNSD & 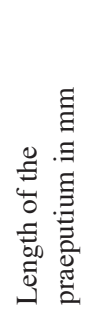 & 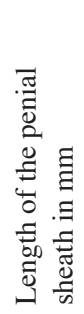 & 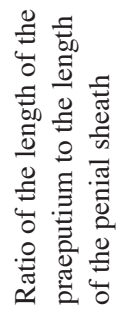 \\
\hline Moll 49707 & 3.5 & 6 & $1: 1.7$ \\
\hline Moll 49708 & 3.5 & 3 & $1.16: 1$ \\
\hline Moll 51276 & 2.5 & 3.5 & $1: 1.4$ \\
\hline Moll 51277 & 2.5 & 3.5 & $1: 1.4$ \\
\hline Moll 51696 & 2.5 & 2 & $1.25: 1$ \\
\hline Moll 51697 & 3 & 2.5 & $1.2: 1$ \\
\hline Moll 51698 & 3.8 & 1.5 & $2.53: 1$ \\
\hline Moll 51699 & 2 & 2 & $1: 1$ \\
\hline Moll 51864 & 1.5 & 1.5 & $1: 1$ \\
\hline Moll 51910 & 3.5 & 3 & 1.16:1 \\
\hline Moll 51964 & 4 & 4 & $1: 1$ \\
\hline Moll 51965 & 3 & 2.5 & $1.2: 1$ \\
\hline Moll 52416 & 3 & 3 & $1: 1$ \\
\hline Moll 52427 & 2.3 & 2 & $1.15: 1$ \\
\hline Moll 52431 & 2 & 2.5 & $1: 1.25$ \\
\hline Moll 52432 & 2 & 3 & $1: 1.5$ \\
\hline Moll 52462 & 2 & 2 & $1: 1$ \\
\hline Moll 52580 & 3 & 3 & $1: 1$ \\
\hline Moll S284 & 3.5 & 4.5 & $1: 1.28$ \\
\hline Moll S2779 & 2.3 & 2 & $1.15: 1$ \\
\hline Moll S2780 & 2 & 2 & $1: 1$ \\
\hline
\end{tabular}




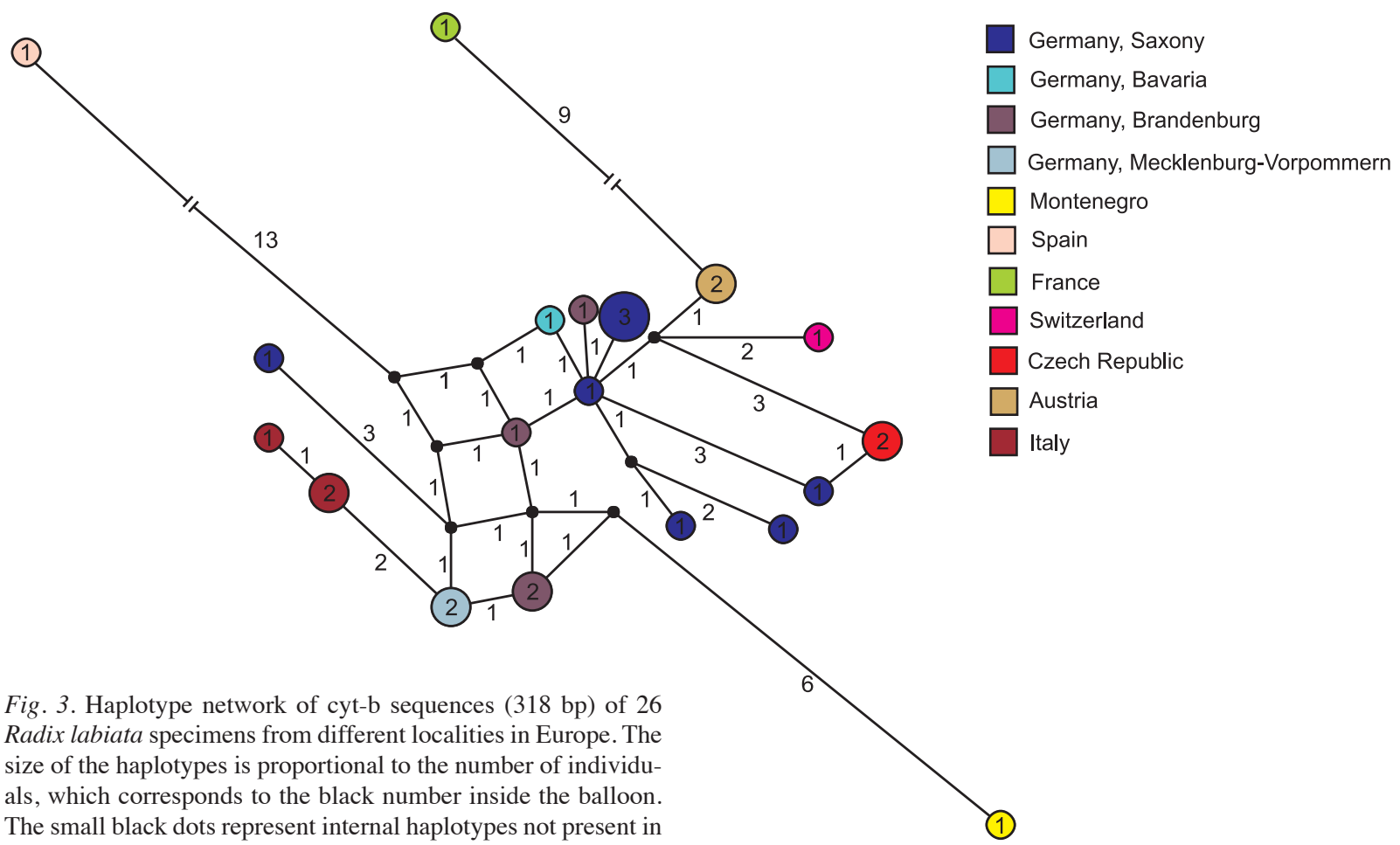
the dataset. The length of the connecting lines is (mostly) proportional to the number of substitutions between haplotypes (reported as black numbers on the lines).

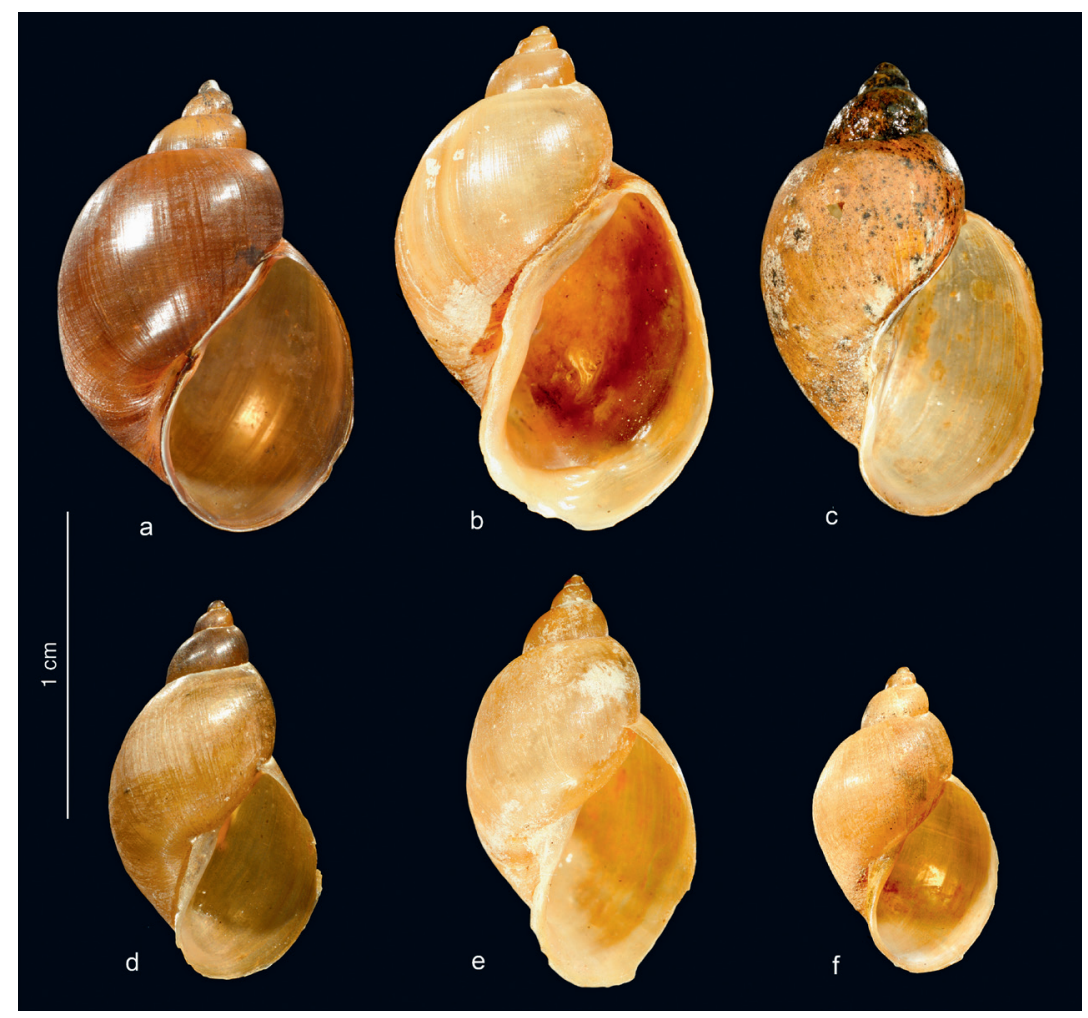

Fig. 4. Variability in Radix labiata shells: a) Germany, Mecklenburg-Vorpommern, Gressow, alder fenwood (Radix labiata 12); b) Switzerland, Basel City, Riehen, well Nollenbrunnen (Radix labiata 23); c) Italy, Lombardy, Province of Brescia, Ponte di Legno, Bleis Lake (Radix labiata 17); d) Germany, Saxony, Ammelshain, quarry Haselberg (Radix labiata 24); e) Austria, Carinthia, Hermagor (Radix labiata 14); f) Germany, Bavaria, spring of the river Strogn near Buchrain (Radix labiata 19). 
to quantify the intraspecific variability in this species. The individuals of $R$. labiata analysed form a clade, which includes a topotype of $R$. labiata from Tharandt (Radix labiata 26) in the MP trees (Figs 1-2) of both the nuclear marker ITS-2 (with full support) and of the mitochondrial cyt-b gene fragment (361 bp) (with very high support). The RAxML trees (not shown) of both markers are also similar in this respect, but whereas the tree based on the ITS-2 sequences yields full support for this clade, support is only $77 \%$ in that based on cyt-b. We conclude that these individuals all belong to one species, $R$. labiata, despite their morphological variability and that they clearly differ from the other Radix species observed. The latter conclusion is confirmed by the large genetic distances based on the cyt$\mathrm{b}$ fragment (Table 1). In the ITS-2 MP tree R. balthica groups as the sister of $R$. ampla and these two species form the sister group to R. lagotis, as Schniebs et al. (2011, Fig. 2) already observed based on an ITS-2 parsimony tree. Together these three species form the sister group to R. labiata. We confirm the opinion given in Schniebs et al. (2011) that the topology of the ITS-2 tree provides a fair reflection of the morphological and anatomical characteristics of the European species of Radix that have been investigated. An explanation of the low support of the basal branches in the RAxML tree could be the incomplete taxon sampling.

The analysis of the network relationship of the mitochondrial haplotypes compared with their geo- graphic origin (Fig. 3) shows that there is no distinct correlation of genetic variability with geography in this relatively small sample of specimens. This result agrees with that found in $R$. balthica (Schniebs et al., 2011).

\section{Morphology}

The variability of the shell of R. labiata (Fig. 4) is less than the variation we found in R. balthica (Schniebs et al., 2011). Shells of $R$. balthica could be confused with these of $R$. auricularia, R. ampla, R. labiata and $R$. lagotis because they could be ear-shaped, amploid to nearly conical egg-shaped (Schniebs et al., 2011, Fig. 4). In most specimens of $R$. labiata the shell is more or less a conical egg-shape, with relatively high first whorls (Fig. 4a), but we also found slender shells shaped nearly like a Stagnicola (Fig. 4d), similar to those Zettler et al. (2006) mentioned for specimens from Mecklenburg-Vorpommern. Gittenberger et al. (1998) also indicated that $R$. labiata could be confused with dwarf forms of Stagnicola palustris (O.F. Müller, 1774). We found considerable variation in shell morphology, even between specimens collected at the same locality (Fig. 5). In all specimens examined the shape of the line tangential to the whorls in adult shells was straight or slightly convex, as already stated in the literature (Glöer, 2002; Stadnichenko, 2004; Kruglov, 2005; Khokhutkin et al., 2009).

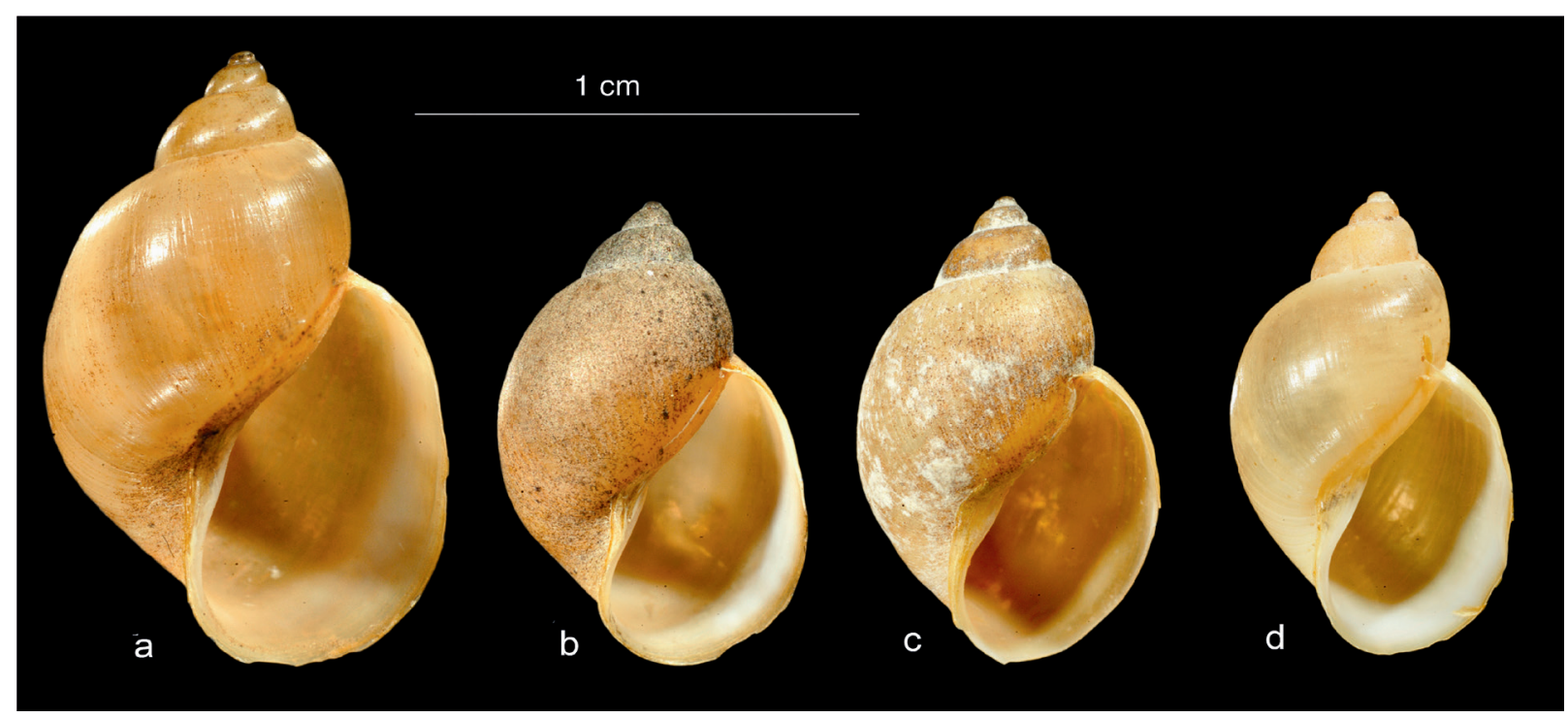

Fig. 5. Variability in Radix labiata shells from specimens collected in the same locality (Germany, Brandenburg, small lake near Wachow, specimens a) and c) identified only by anatomy as R. labiata, specimens b) (Radix labiata 7) and d) (Radix labiata 6) are sequenced and identified by anatomy as well). 

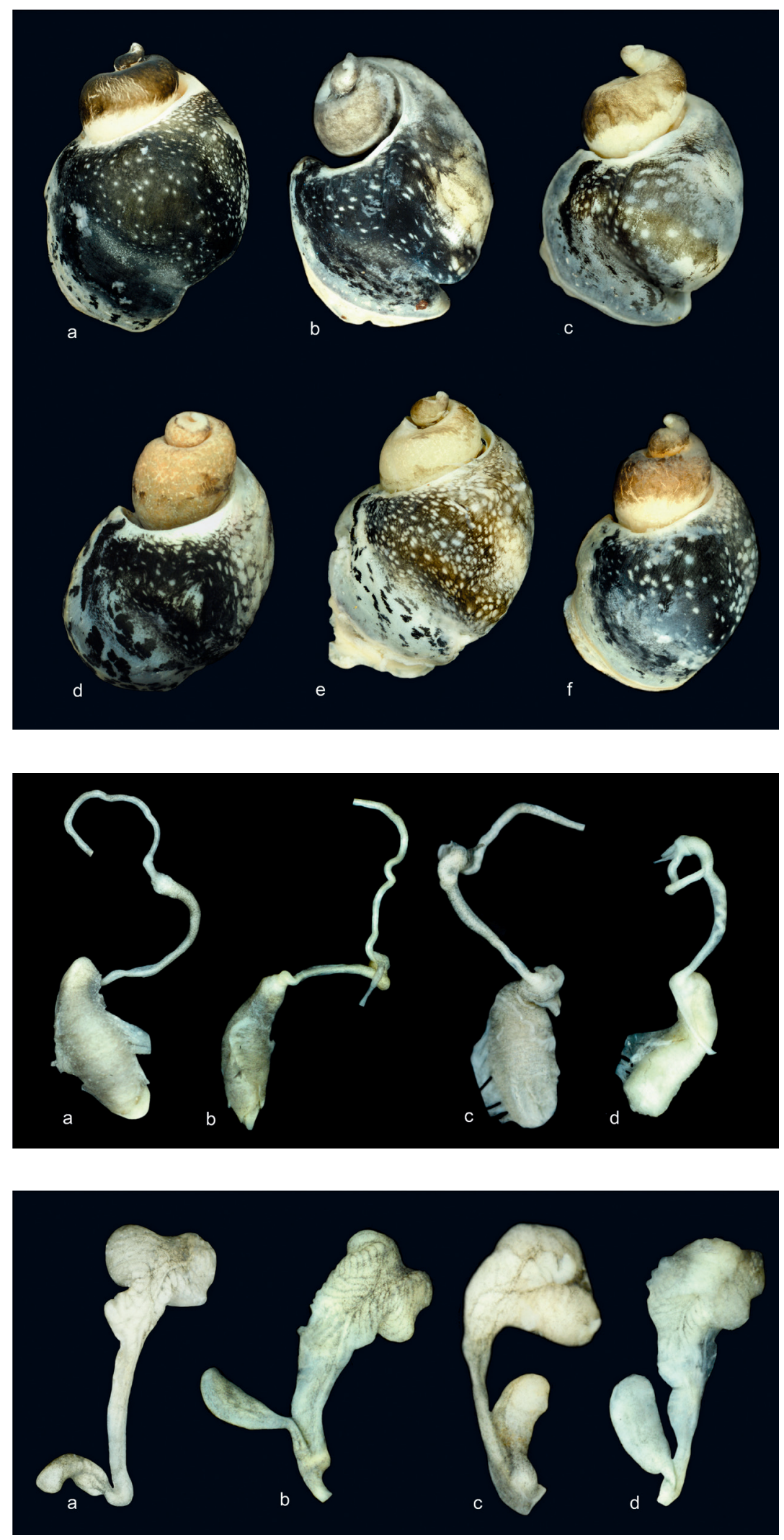

Fig. 6. Variability in Radix labiata mantle pigmentation: a) Germany, Mecklenburg-Vorpommern, Gressow, alder fenwood (Radix labiata 12); b) Switzerland, Basel City, Riehen, well Nollenbrunnen (Radix labiata 23); c) Italy, Lombardy, Province of Brescia, Ponte di Legno, Bleis Lake (Radix labiata 17); d) Germany, Saxony, Ammelshain, quarry Haselberg (Radix labiata 24); e) Austria, Carinthia, Hermagor (Radix labiata 14); f) Germany, Bavaria, spring of the river Strogn near Buchrain (Radix labiata 19).

Fig. 7. Variability in Radix labiata male genitalia: a) Germany, MecklenburgVorpommern, Gressow, alder fenwood (Radix labiata 12); b) Germany, Bavaria, spring of the river Strogn near Buchrain (Radix labiata 19); c) Italy, Lombardy, Province of Brescia, Ponte di Legno, Bleis Lake (Radix labiata 17); d) Germany, Saxony, Ammelshain, quarry Haselberg (Radix labiata 24).

Fig. 8. Variability of the form of the bursa copulatrix and the length of the bursa duct in Radix labiata: a) Germany, Mecklenburg-Vorpommern, Gressow, alder fenwood (Radix labiata 12); b) Germany, Bavaria, spring of the river Strogn near Buchrain (Radix labiata 19) c) Italy, Lombardy, Province of Brescia, Ponte di Legno, Bleis Lake (Radix labiata 17); d) Germany, Saxony, Ammelshain, quarry Haselberg (Radix labiata 24). 
The maximum shell height reported here is exceeded in R. labiata from Ukraine (up to $21.4 \mathrm{~mm}$; see Stadnichenko, 2004). In Western Siberia shells of this species can reach a height of $18.4 \mathrm{~mm}$ (Andreeva et al., 2010). Possibly, R. labiata has the smallest shell height amongst European species of Radix.

Typical mantle pigmentation in R. labiata is irregular, fine, whitish, blurred dots of similar size on a black, or deep blue-black, mantle, as already mentioned in the literature (Glöer, 2002; Stadnichenko, 2004, see also Fig. 5a). Normally this mantle pigmentation renders this species distinguishable from the other European Radix species examined because only a few large white spots on dark background are typical for $R$. auricularia and $R$. ampla whereas the typical mantle pigmentation of $R$. balthica and $R$. lagotis shows medium-sized spots on dark background (see Schniebs et al., 2011; Table 2). But we found also $R$. labiata with larger dots (Fig. 6c), which means that it would be difficult to distinguish this species from $R$. balthica on the basis of the mantle pigmentation alone.

In our specimens examined $(n=21)$ the length of the praeputium varied from 1.5 to $4 \mathrm{~mm}$ and that of penial sheath from 1.5 to $6 \mathrm{~mm}$ (Table 2). The ratio of the length of the praeputium to the length of the penial sheath varied from 0.58 to 2.53 (Fig. 7, Table 2). In six of these the praeputium was longer than the penial sheath $(1.15: 1,1.16: 1,1.2: 1,1.25: 1$ (2x), 2.53:1) (Table $2)$. We thus found more variability in this characteristic than is recognised in the literature. Meier-Brook in Glöer (2002, p. 217) reported that the length ratio of praeputium to penial sheath can vary from $0.7: 1$ to 2.3:1. Kruglov and Starobogatov (1983) and Kruglov (2005) gave a value of 0.66 and Stadnichenko (2004) a ratio of 1:1.5. Khokhutkin et al. (2009) mentioned that in four specimens from the Urals the ratio of the length of the praeputium to the length of the penial sheath varied from 0.71 to 0.84 . The enormous variability of this character confirms our statement (Schniebs et al., 2011) that it is not useful for differentiating $R$. labiata from $R$. balthica. The latter has a ratio of the length of the praeputium to the length of the penial sheath from 0.7 to 1.3 (Schniebs et al., 2011). It should also be noted that in certain Radix species this ratio may be polymorphic within a population, and conchologically indistinguishable individuals may differ drastically from each other in penial sheath length (Vinarski, 2011). In the present study the length of the praeputium varies from 2 to $3.8 \mathrm{~mm}$ within four specimens of one population in Brandenburg (Germany) (collection No. SNSD Moll 51696-51699) (Table 2). This may consti- tute another cause of high variation in the proportions of the copulatory organ.

To the usual uniform grey or grey greenish pigmentation of the praeputium already described (Schniebs et al., 2011) we can add a whitish-yellow colour in two of the 21 examined specimens.

We could confirm that the position of the bursa copulatrix behind (ventral to) the provaginal duct and vagina is indeed typical for $R$. labiata (Stadnichenko, 2004; Kruglov, 2005; Schniebs et al., 2011). The variability is similar to that illustrated in Hubendick (1953: p. 28, Figs 22-24). Of all examined European Radix, we found this position of the bursa only in R. labiata, thus we can suppose that the specimens shown by Hubendick, 1953 belong to R. labiata. Only in three specimens out of the 20 examined the bursa was positioned beside the provaginal duct. But in these cases the bursa duct also entered on the ventral side of the provaginal duct.

We showed that the length of the bursa duct (Fig. 8) varies more than indicated in the current literature used for determination of freshwater molluscs: Glöer (2002) and Kruglov (2005) mentioned only that $R$. labiata has a short bursa duct, Huňova et al. (2012) described the bursa duct as shorter than half-length of bursa copulatrix, whereas Stadnichenko (2004, p. 200) provides the information that the bursa duct could be as long as the diameter of the bursa or the diameter of the bursa can clearly be longer than the length of the bursa duct. In 7 of 21 specimens examined for this study the bursa duct was nearly not visible (Fig. 8a). Hubendick (1953: p. 28, Figs 22-24) found nearly the same extent of the variability of the bursa duct as we did.

In summary, the length of the bursa duct in $R$. labiata varies from nearly not visible to one third of the length of the bursa. This overlaps with the length of the bursa duct we found in $R$. balthica from between nearly not visible to half of the length of the bursa (Schniebs et al., 2011). This is a further reason to confirm our former statement (Schniebs et al., 2011) that the length of the bursa duct is not a good character to differentiate $R$. labiata from $R$. balthica whereas the position of the bursa is.

\section{Conclusions}

In Central Europe, $R$. labiata can be confused mainly with specimens of $R$. lagotis and R. balthica with slender shells (Fig. 9a-b) and with representatives of the genus Stagnicola (Fig. 9c). The results of this present 


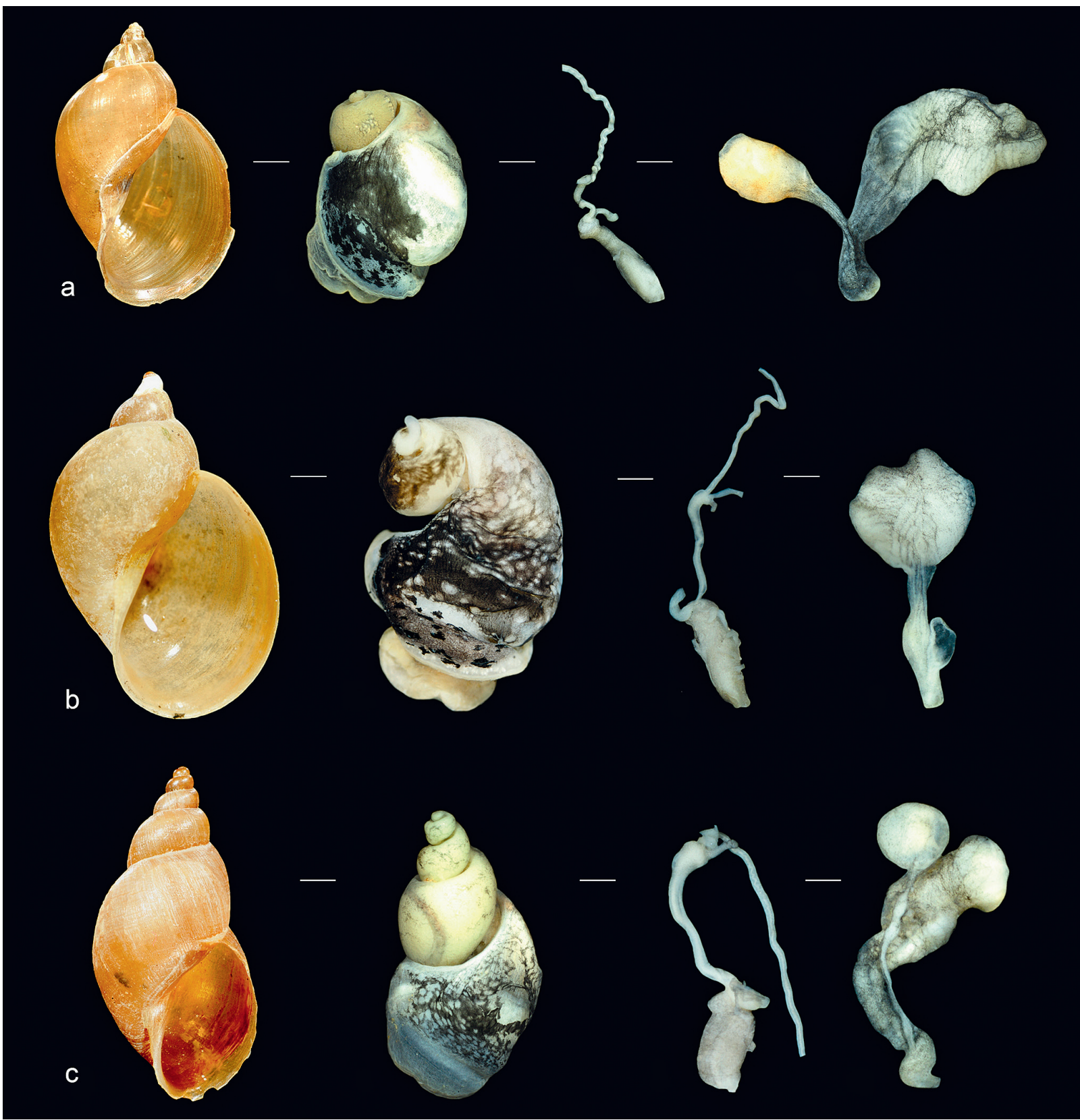

Fig. 9. a) Radix lagotis (Germany, Saxony, pond Kleiner Kirchenteich near Grethen); b) Radix balthica (France, Region Centre, Thenay); c) Stagnicola palustris (Germany, Saxony, Dresden, small pond in the valley of the spring Kaitzbach).

study confirm our earlier conclusions concerning the differentiation of $R$. labiata from $R$. balthica (Schniebs et al., 2011) that the clearest anatomical character is the position of the bursa and the bursa duct: in most specimens of $R$. labiata they lie ventrally to the vagina and the provaginal duct. Additionally, we discovered that sometimes bursa and bursa duct can lie beside the provaginal duct. The shells of $R$. labiata usually have a straight line tangential to the whorls in adult shells, whereas in $R$. balthica it is usually convex or rarely concave (Schniebs et al., 2011).

Radix lagotis specimens with slender shells and dark mantle pigmentation also differ from $R$. labiata 
in the positions of the bursa and the bursa duct and by the length of the bursa duct: in R. lagotis, bursa and bursa duct lie above (dorsal to) the provaginal duct, and vagina, uterus and prostate, and the bursa duct is $1 / 2$ to about $2 / 3$ of the length of the bursa (if filled) (Fig. 9a; see also Schniebs et al., 2011).

Specimens of $R$. labiata with a shell similar to representatives of the genus Stagnicola can be distinguished by the much shorter bursa duct and by the position of the bursa, which lies near the pericardium in Stagnicola (Fig. 9c) and not ventral to vagina and provaginal duct, as in R. labiata.

\section{Acknowledgements}

We would like to express our thanks to Prof. Dr Uwe Fritz (SNSD) for financial support for the greater part of the molecular analyses, Anke Müller (SNSD) for some sequences and the instructions of KS in lab work, as well as Dr André Reimann (SNSD), Dr Michael L. Zettler (Leibnitz Institute for Baltic Sea Research Warnemünde), Michael Korn (University of Konstanz, Limnological Institute), Dr Nicole Schröder-Rogalla (Munich), Susanne Thiel (Munich), Kateřina Huňova (Prague), Robert Haldemann (Strausberg), Christoph Oberer (Natural History Museum Basel), Prof. Dr Vladimir Pešić (University of Montenegro), Dr Ulrich Bössneck (Erfurt-Vieselbach), Dr Heike Reise (SMNG Görlitz), Eric Gallerne (Leguevin), Gerhard Falkner (State Museum of Natural History Stuttgart), Holger Menzel-Harloff (Wismar), Uwe Jueg (Ludwigslust), Hajo Kobialka (Höxter), Dr Alfried V. Karimov (Omsk State Pedagogical University), Willy de Mattia (Muggia), Gianbattista Nardi (Nuvolera), Ivano Niero (Spinea), Antonio Braccia (Brescia), Dr Ira Richling (State Museum of Natural History Stuttgart), Andrea Pohl (Dresden), Gudrun Rutsch (Dresden) and Christa Schniebs (Oelsnitz) for the material collected and provided. We thank Dr John M. C. Hutchinson (Senckenberg Museum of Natural History Görlitz) for proof reading an earlier version of the manuscript. We also thank three anonymous reviewers for their comments which improved the manuscript.

\section{References}

Andreeva SI, Andreev NI, Vinarski MV. 2010. Families Acroloxidae and Lymnaeidae. P. 200. in: Key to freshwater gastropods of Western Siberia (Mollusca: Gastropoda). V. 1. Gastropoda: Pulmonata. Fasc. 1. Omsk. [in Russian]

Angelov AM. 2000. Mollusca (Gastropoda et Bivalvia) aquae dulcis. Pp. XIV + 57. In: Catalogus Faunae Bulgaricae 4. Sofia, Leiden: Pensoft \& Backhuys Publishers.

Bandelt H-J, Forster P, Rohl A. 1999. Median-joining networks for inferring infraspecific phylogenies. Molecular Biology and Evolution 16:37-48.

Bank R. 2011. Fauna Europaea project. Systematical and distributional checklist of species-group taxa of continental Mollusca of Europe, version 2.4. <www.faunaeur.org>
Caron Y, Lasri S, Losson B. 2007. Fasciola hepatica: An assessment on the vectorial capacity of Radix labiata and $R$. balthica commonly found in Belgium. Veterinary Parasitology 149: 95-103.

Falkner G, Bank RA, von Proschwitz T. 2001. Check-list of the non-marine Molluscan Species-group taxa of the States of Northern, Atlantic and Central Europe (CLECOM 1). Heldia $4: 1-76$.

Gittenberger E, Janssen AW, Kuijper WJ, Kuiper JGJ, Meijer T, van der Velde G, de Vries JN. 1998. De Nederlandse Zoetwatermollusken. Recente en fossiele weekdieren uit zoet en brak water. P. 288 in: Gittenberger E, Janssen AW, eds, Nederlandse Fauna 2. Leiden, Utrecht: Nationaal Natuurhistorisch Museum Naturalis, KNNV Uitgeverij, European Invertebrate Survey - Nederland.

Glöer P. 2002. Die Süßwassergastropoden Nord- und Mitteleuropas. P. 327. In: Die Tierwelt Deutschlands 73. Hackenheim: Conchbooks.

Glöer P, Diercking R. 2010. Atlas und Rote Liste der Süßwassermollusken in Hamburg. Behörde für Stadtentwicklung und Umwelt, Freie und Hansestadt Hamburg.

Hall TA. 1999. BioEdit: a user friendly biological sequence alignment editor and analysis program for Windows 95/98/ NT. Nucleic Acids Symposium Series no. 41: 95-98.

Hartmann JDW. 1840-1844. Erd- und Süßwasser-Gasteropoden der Schweiz. Mit Zugabe einiger merkwürdigen exotischen Arten I. Pp. XX + 227. St. Gallen: Scheitlin \& Zollikofer.

Hubendick B. 1953. Recent Lymnaeidae. Their variation, morphology, taxonomy, nomenclature, and distribution. Kungliga Svenska Vetenskapsakademiens Handlingar Series 4, 3(1): 1-223.

Huňova K, Kašný M, Hampl V, Leontovyč R, Kuběna A, Mikeš L, Horák P. 2012. Radix spp.: Identification of trematode intermediate hosts in the Czech Republic. Acta Parasitologica 57: 273-284.

Khokhutkin IM, Vinarski MV, Grebennikov ME. 2009. The family Lymnaeidae (Gastropoda, Pulmonata, Lymnaeiformes). Pp. 1-156. In: Molluscs of the Urals and the adjacent areas1. Yekaterinburg, Goshchitskiy Publishers. [in Russian]

Kruglov ND. 2005. Lymnaeid snails (Lymnaeidae Gastropoda Pulmonata) of Europe and Northern Asia .P. 507. Smolensk State Pedagogical University Press. [in Russian]

Kruglov ND, Starobogatov YI. 1983. A contribution to the morphology and taxonomy of European representatives of the subgenus Peregriana (Lymnaea, Gastropoda, Pulmonata). Zoologichesky Zhurnal 62: 1462-1473. [in Russian].

Linnaeus C von. 1758. Systema naturae per regna tria naturae, secundum classes, ordines, genera, species, cum characteribus, differentiis, synonymus, locis. Tomus I. Editio decima, reformata. Pp. 1-824. Laurentius Salvius: Holmiae.

Müller OF. 1774. Vermium terrestrium et fluviatilum, seu animalium infusorium, helminthicorum et testaceorum, non marinorum, succincta historia. Vol. 2. Pp. I-XXVI, 1-214. Heineck et Faber: Havniae et Lispiae.

Reise K, Glöer P. 2006. Limnische Molluskenfauna einer Nordseeinsel - verändert nach 40 Jahren. Heldia 6 (3/4): 153-167.

Rossmässler EA. 1835-1844. Iconographie der Land- und Sü $\beta$ wasser-Mollusken, mit vorzüglicher Berücksichtigung der europäischen noch nicht abgebildeten Arten 1(1). Dresden, Leipzig: Arnoldische Buchhandlung [1835]. 
Schniebs K, Glöer P, Vinarski MV, Hundsdoerfer AK. 2011. Intraspecific morphological and genetic variability in Radix balthica (Linnaeus, 1758) (Gastropoda: Basommatophora: Lymnaeidae) with morphological comparison to other European Radix species. Journal of Conchology 40: 657-678.

Schrank FVP. 1803. Durchdachte Geschichte der in Baiern einheimischen und zahmen Tiere. - Nacktschnecken und Schalthiere. Fauna Boica 3 (2): 250-301.

Silvestro D, Michalak I. 2010. RAXMLGUI: a graphical frontend for RAxML. Available at http://sourceforge.net/projects /raxmlgui/.

Stadnichenko AP. 2004. Lymnaeidae and Acroloxidae of the Ukraine. P. 327. Kiev: Center of textbooks. [in Russian]

Stamatakis A, Ludwig T, Meier H. 2005. Raxml-iii: a fast programm for maximum likelihood-based inference of large phylogenetic trees. Bioinformatics 21: 456-463.

Swofford DL. 2002. PAUP. Phylogenetic analysis using parsimony (and other methods), version 4. Sunderland: Sinauer Associates.

Tamura K, Dudley J, Nei M, Kumar S. 2007. MEGA4: molecular evolutionary genetics analysis (MEGA) software version 4.0. Molecular Biology and Evolution 24: 1596-1599.

Turner H, Kuiper JGJ, Thew N, Bernasconi R, Rüetschi J, Wüthrich M, Gostelli M. 1998. Atlas der Mollusken der Schweiz und Liechtensteins. Fauna Helvetica 2.

Vinarski MV. 2011. The 'index of the copulatory apparatus' and its application to the systematics of freshwater pulmonates
(Mollusca: Gastropoda: Pulmonata). Zoosystematica Rossica 20: 11-27.

Vinarski MV, Andreeva SI, Andreev NI, Lazutkina EA, Karimov AV. 2008. Diversity of gastropods in the inland waterbodies of Western Siberia. Invertebrate Zoology 4: 173-183.

Vinarski MV, Schniebs K, Glöer P, Hundsdoerfer AK. 2011. The taxonomic status and phylogenetic relationships of the genus Aenigmomphiscola Kruglov et Starobogatov, 1981 (Gastropoda: Pulmonata: Lymnaeidae). Journal of Natural History 45: 2049-2068.

Ward PI, Goater CP, Mikos M. 1996. Shell variation in sympatric freshwater Lymnaea peregra and L. ovata (Gastropoda: Lymnaeidae). Biological Journal of the Linnean Society 61: 139-149.

Welter-Schultes F. 2012. European non-marine molluscs, a guide for species identification. P. 679. Göttingen: Planet Poster Editions.

Zettler ML, Jueg U, Menzel-Harloff H, Göllnitz U, Petrick S, Weber E, Seemann R. 2006. Die Land- und Süßwassermollusken Mecklenburg-Vorpommerns. P. 318. Schwerin: Obotritendruck.

Received: 19 June 2012

Revised and accepted: 8 January 2013

Published online: 28 February 2013

Editor: M. Schilthuizen 


\section{Appendix}

Material used for the molecular genetic and morphological analyses. ENA = European Nucleotide Archive.

\begin{tabular}{|c|c|c|c|c|}
\hline \multirow[t]{2}{*}{ Code } & \multirow{2}{*}{$\begin{array}{l}\text { Collection } \\
\text { No. SNSD }\end{array}$} & \multirow[t]{2}{*}{ Locality } & \multicolumn{2}{|l|}{ ENA No. } \\
\hline & & & cyt-b & ITS-2 \\
\hline \multicolumn{5}{|c|}{ Planorbarius corneus (Linnaeus, 1758) } \\
\hline P. corneus 1 & Moll 52556 & 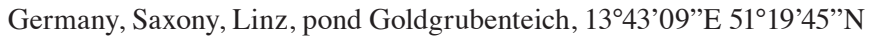 & FR797880 & FR797830 \\
\hline P. corneus 2 & Moll 52557 & Germany, Saxony, Linz, pond Goldgrubenteich, $13^{\circ} 43^{\prime} 09^{\prime \prime E} 51^{\circ} 19^{\prime} 45^{\prime \prime} \mathrm{N}$ & FR797881 & FR797831 \\
\hline
\end{tabular}

Lymnaea stagnalis (Linnaeus, 1758)

L. stagnalis $1 \quad$ Moll 49239 Germany, Saxony, Dresden-Zschieren, old branch of river Elbe,

HE573102 HE573064

1352’28”E 5059'50”N

L. stagnalis 2 Moll 49835 Germany, Saxony, Niederspree, small pond, 1454'03"E 51²4'28'N

HE573103 HE573065

L. stagnalis 3 Moll 53108 Germany, Baden-Württemberg, Konstanz-Egg, ditch Hockgraben,

FR797894 FR797834

L. stagnalis 4 Moll 53109 Germany, Baden-Württemberg, Konstanz-Egg, ditch Hockgraben, 9॰11'34.2”E 4740'57.3”'N

FR797895 FR797835

Radix auricularia (Linnaeus, 1758)

R. auricularia 1 Moll 50005 Germany, Saxony, Niederspree, pond Neuwiesenteich,

HE573104 HE573066 $14^{\circ} 52^{\prime} 57^{\prime \prime} \mathrm{E} 51^{\circ} 24^{\prime} 19$ '” N

R. auricularia 2 Moll 50079 Germany, Saxony, pond Vierteich near Freiteilsdorf,

HE573105 HE573067 $13^{\circ} 41^{\prime} 57^{\prime \prime} \mathrm{E} 51^{\circ} 15^{\prime} 43^{\prime \prime} \mathrm{N}$

R. auricularia 3 Moll 53070 Germany, Bavaria, Weichering, pond in riverside forest,

FR797902 FR797842 11'19'23.6”'E 4843’34.1”N

R. auricularia 4 Moll 53071 Germany, Bavaria, Weichering, pond in riverside forest, 11'19'23.6’'E 4843'34.1'”N

FR797903 FR797843

Radix balthica (Linnaeus, 1758)

R. balthica 1 Moll 51283 Switzerland, canton Basel-Landschaft, Liestal, Orishof,

HE573133 HE573082 $07^{\circ} 43^{\prime} 03^{\prime \prime} \mathrm{E} 47^{\circ} 28^{\prime} 22^{\prime \prime} \mathrm{N}$

R. balthica 2 Moll 51834 Germany, Saxony, Dresden-Kleizschachwitz, river Elbe,

HE573119 HE573079

R. balthica 3 Moll 53111 Germany, Baden-Württemberg, Konstanz-Egg, pond near University,

HE573116 HE573078

R. balthica 4 Moll 53112 Germany, Baden-Württemberg, Konstanz-Egg, pond near University,

HE573117 HE577649 0911'29'E 4741'09'”

Radix lagotis (Schrank, 1803)

\begin{tabular}{|c|c|c|c|c|}
\hline AJ319638 & - & Czech Republic, Kadov, Vasi and Podkadovsky pond & - & AJ319638 \\
\hline AJ319639 & - & Austria, Schoenau, southeast of Vienna & - & AJ319639 \\
\hline R. lagotis 1 & Moll 49868 & $\begin{array}{l}\text { Germany, Saxony, pond Vierteich near Freiteilsdorf, } \\
13^{\circ} 41^{\prime} 57^{\prime} \text { 'E } 51^{\circ} 15^{\prime} 43^{\prime \prime}\end{array}$ & HE573114 & HE573076 \\
\hline R. lagotis 2 & Moll 52563 & Saxony, pond Goldgrubenteich near Linz, $13^{\circ} 43^{\prime} 09^{\prime \prime} \mathrm{E} 51^{\circ} 19^{\prime} 46^{\prime \prime} \mathrm{N}$ & HE573115 & HE573077 \\
\hline$R$. lagotis 3 & Moll 53239 & Saxony, dam Doellnitzsee near Mutzschen, $12^{\circ} 55^{\prime} 18^{\prime \prime E} 51^{\circ} 15^{\prime} 45^{\prime \prime} \mathrm{N}$ & HE573113 & HE573075 \\
\hline \multicolumn{5}{|c|}{ Radix ampla (Hartmann, 1821) } \\
\hline R. ampla 1 & Moll 51112 & $\begin{array}{l}\text { Russia, Chelyabinsk Region, river Miass near Dynamo village, } \\
60^{\circ} 02^{\prime} \mathrm{E} 45^{\circ} 57^{\prime} \mathrm{N}\end{array}$ & HE798470 & HE798448 \\
\hline R. ampla 2 & Moll 51113 & $\begin{array}{l}\text { Russia, Chelyabinsk Region, river Miass near Dynamo village, } \\
60^{\circ} 02^{\prime} \mathrm{E} 45^{\circ} 57^{\prime} \mathrm{N}\end{array}$ & HE798471 & HE798449 \\
\hline R. ampla 3 & Moll 53098 & Germany, Bavaria, lake Ammersee, Stegen, $11^{\circ} 08^{\prime} 07^{\prime} \mathrm{E} 48^{\circ} 04^{\prime} 32^{\prime \prime} \mathrm{N}$ & HE573110 & HE573072 \\
\hline R. ampla 4 & Moll 53099 & Germany, Bavaria, lake Ammersee, Stegen, $11^{\circ} 08^{\prime} 07^{\prime \prime} \mathrm{E} 48^{\circ} 04^{\prime} 32^{\prime \prime N}$ & HE573111 & HE573073 \\
\hline R. ampla 5 & Moll S2193 & $\begin{array}{l}\text { Germany, Mecklenburg-Western Pomerania, lake Luebkowsee } \\
2 \mathrm{~km} \text { E of Schwichtenberg, } 13^{\circ} 44.567^{\prime} \mathrm{E} 53^{\circ} 40.967^{\prime} \mathrm{N}\end{array}$ & HE573112 & - \\
\hline
\end{tabular}


Cont.

\begin{tabular}{llcc}
\hline Code & Collection & Locality & ENA No. \\
\hline & No.SNSD & cyt-b & ITS-2 \\
\hline
\end{tabular}

Radix labiata (Rossmässler, 1835

R. labiata $1 \quad$ Moll 49707 Czech Republic, České Budějovice, Ponesice, 14²8'60"E 4906'00”N

R. labiata $2 \quad$ Moll 49708

R. labiata $3 \quad$ Moll 51275

R. labiata $4 \quad$ Moll 51276

R. labiata $5 \quad$ Moll 51277

R. labiata $6 \quad$ Moll 51696

R. labiata 7

R. labiata 8

Moll 51697

R. labiata 9

R. labiata 10

R. labiata 11

R. labiata 12

R. labiata 13

R. labiata 14

R. labiata 15

R. labiata 16

R. labiata 17

R. labiata 18

R. labiata 19

R. labiata 20

R. labiata 21

\section{R. labiata 22}

R. labiata 23

R. labiata 24

R. labiata 25

R. labiata 26

Czech Republic, České Budějovice, Ponesice, $14^{\circ} 28^{\prime} 60^{\prime \prime} \mathrm{E} 49^{\circ} 06^{\prime} 00^{\prime \prime} \mathrm{N}$ Germany, Saxony, pond near Langenberg, 12 51'21'E 50³3'09'N

Germany, Saxony, pond near Langenberg, 1251'21'E 50³3'09'N

Germany, Saxony, pond near Langenberg, 1251'21'E 50³3'09'N

Germany, Brandenburg, small lake near Wachow, $12^{\circ} 43^{\prime} 05^{\prime \prime} \mathrm{E} 52^{\circ} 32^{\prime} 05^{\prime} \mathrm{N}$

Germany, Brandenburg, small lake near Wachow, $12^{\circ} 43^{\prime} 05^{\prime \prime} \mathrm{E} 52^{\circ} 32^{\prime} 05^{\prime}$ 'N

Moll 51698 Germany, Brandenburg, small lake near Wachow, $12^{\circ} 43^{\prime} 05^{\prime \prime}$ E $52^{\circ} 32^{\prime} 05^{\prime \prime} \mathrm{N}$

Moll 51699 Germany, Brandenburg, small lake near Wachow, 1243'05'"E 52॰32'05'N

Moll 51863 Montenegro, Žabljak, Black Lake, sand pools, $19^{\circ} 05^{\prime} 42^{\prime \prime E} 43^{\circ} 08^{\prime} 50^{\prime \prime N}$

Moll 51910 Germany, Saxony, Dehnitz, renatured swimming baths, $12^{\circ} 44^{\prime} 24^{\prime \prime}$ E 5120'56”'N

Moll 51964 Germany, Mecklenburg-Western Pomerania, Gressow, alder fenwod, $11^{\circ} 18.592^{\prime} \mathrm{E} 53^{\circ} 41.898^{\prime} \mathrm{N}$

Moll 51965 Germany, Mecklenburg-Western Pomerania, Gressow, alder fenwod, $11^{\circ} 18.592^{\prime} \mathrm{E} 53^{\circ} 41.898^{\prime} \mathrm{N}$

Moll 52415 Austria, Carinthia, Hermagor, $13^{\circ} 22^{\prime} \mathrm{E} 46^{\circ} 37^{\prime} \mathrm{N}$

Moll 52416 Austria, Carinthia, Hermagor, 13²2'E 46³7’ N

Moll 52427

Italy, Lombardy, Province of Brescia, Borno, lower Varicla Lake, $2^{\circ} 15$ '24”'W 45॰58'50”'N (Monte Mario)

Moll 52431 Italy, Lombardy, Province of Brescia, Ponte di Legno, Bleis Lake, 1'53'39'” 4616'52'N (Monte Mario)

Moll 52432 Italy, Lombardy, Province of Brescia, Ponte di Legno, Bleis Lake, 153'39'W 46¹6'52'N (Monte Mario)

Moll 52462 Germany, Bavaria, spring of the river Strogn near Buchrain, $11^{\circ} 58^{\prime} 41^{\prime \prime} \mathrm{E} 48^{\circ} 13^{\prime} 24^{\prime \prime} \mathrm{N}$

Moll 52580 Germany, Saxony, Linz, five year old pond, 1343'33'E 51²0'51'N

Collection

U. Bößneck, Spain, Santa Marina del Valdeon, Vega de Liordes, marshy headwater TissueInver 3956

Moll S172

Moll S284 region, $1940 \mathrm{~m}, 4^{\circ} 50$ '09' $\mathrm{W} 43^{\circ} 09^{\prime} 11^{\prime \prime} \mathrm{N}$

France, Bourgogne, Département Cote-d'Or

Switzerland, Basel City, Riehen, well Nollenbrunnen, 7०40'17''E 47³4'41'’ N

Moll S2779

Germany, Saxony, Ammelshain, quarry Haselberg, 12॰39'16"'E 51¹7'49”'N

Moll S2780 Germany, Saxony, Ammelshain, quarry Haselberg, 12॰39'16'"E 51¹7'49”N

Moll S2904 Germany, Saxony, small brook north of Tharandt, $13^{\circ} 34^{\prime} 19^{\prime \prime} \mathrm{E} 51^{\circ} 00^{\prime} 08^{\prime \prime} \mathrm{N}$

\begin{tabular}{ll} 
HE798472 & HE798450 \\
HE798473 & HE798451 \\
HE798474 & - \\
HE798475 & HE573069 \\
HE798476 & HE798452 \\
HE798477 & HE577648 \\
HE798478 & HE573070 \\
HE798479 & HE573071 \\
HE798480 & HE798453 \\
HE798507 & HE798455 \\
HE798481 & HE798456 \\
HE798482 & HE798454 \\
HE798483 & - \\
\hline HE798484 & HE798457 \\
HE798485 & HE798458 \\
HE798486 & HE798459 \\
HE798487 & HE798460 \\
HE798488 & HE798461 \\
HE798489 & HE798462 \\
& \\
\hline & \\
HE798490 & HE798463 \\
HE798464
\end{tabular}

HE798492 HE798465

HE798493 HE798466

HE798494 HE798467

HE798495 HE798468

HE798496 HE798469 